HOW Journal

Volume 26, Number 2, pages 59-74.

https://doi.org/10.19183/how.26.2.506

HOW

\title{
Was I Being Critical? Vision and Action in English Language Teacher Education
}

\author{
¿Estaba siendo crítico? Visión y acción en la formación docente \\ en inglés
}

\author{
Basabe, Enrique Alejandro ${ }^{1}$
}

\begin{abstract}
Criticality has recently made its way into the field of English Language Teaching. It has mainly fostered the study of teachers' individual commitments with their social context. A reflective account is offered here based on my praxis when I adopted a critical pedagogy to teach literature in the English language teacher education program at the National University of La Pampa (UNLPam) in Argentina. Drawing on observations and documents, I give in this paper an autoethnographic account of my practice. The results show that I maintained a constant questioning of my practice and a persistent wariness about the appropriateness of keeping a critical position in my teaching context. All teachers should perform these two reflective actions in view of our role as socially and pedagogically responsible agents of practice.
\end{abstract}

Keywords: teacher education, critical pedagogies, practice theory, autoethnographic narratives.

\section{Resumen}

Lo crítico ha logrado instalarse en el campo de la enseñanza de inglés como lengua extranjera y ha motivado investigaciones sobre los compromisos docentes individuales con el contexto social. Se ofrece aquí una narrativa reflexiva de mi praxis al adoptar una pedagogía crítica para la enseñanza de la literatura en el Profesorado en Inglés de la Universidad Nacional de La Pampa (UNLPam) en Argentina. Basado en observaciones y documentos, el trabajo se erige como una autoetnografía que revisa mi

Enrique Alejandro Basabe is a lecturer in the Department of Foreign Languages at Universidad Nacional de La Pampa (UNLPam), Argentina. He holds an MA in ELT and BCS and a PhD in Education. His main interests are teacher education and cultural issues in the English, American, and Latin American contexts. eabasabe@humanas.unlpam.edu.ar https://orcid.org/0000-0003-3747-8035

Received: January 18th, 2019. Accepted: July 5th, 2019

This article is licensed under a Creative Commons Attribution-Non-Commercial-No-Derivatives 4.0 International License. License Deed can be consulted at https://creativecommons.org/licenses/by-nc-nd/4.0/ 
labor docente. Los resultados muestran una inquisitiva reflexión sobre mi práctica docente y una duda constante sobre lo apropiado de mantener una postura crítica en mi contexto laboral, ambas actitudes que todos los docentes deberíamos tener en vista de nuestro rol de agentes social y pedagógicamente responsables de nuestras prácticas.

Palabras clave: formación docente, pedagogías críticas, teoría de la práctica, narrativas autoetnográficas.

\section{Introduction}

As stated by Richards and Lockhart (1996), "critical reflection can trigger a deeper understanding of teaching," (p. 4) which in turn may lead to change. Reflective practice in English language teaching (ELT) has been reported to be positive not only for novice teachers (Farrell, 2012) but also for experienced teachers (Farrell, 2011) since it offers different perspectives about how we construct a conceptual sense of our vision and action. In this paper, I offer a reflective autoethnographic narrative of my praxis as a teacher educator who adopted a critical pedagogy to teach literature in the English language teacher education (ELTE) program at the National University of La Pampa (UNLPam) in Argentina. Canagarajah (2012) and Tsui (2007) used autoethnography and narrative inquiry, respectively, to delve into the development of the professional identities of ELT practitioners and offered valuable insight into the intricacies of teacher agency and identity in a global context.

At the time covered by this narrative, my practice was framed by the teaching and research project Critical literacy and literature in English language teacher education (Basabe \& Germani, 2013). Grounded on ethnographic observation and document analysis, the project sought to study the design and practice of a series of experiences that, without disregarding the more usual approaches to the teaching of literature, would integrate those derived from a linguistic reading of literary texts with those advocating for critical reading and for the creation of open spaces of debate. Results have been reported elsewhere (Arriaga \& Germani, 2018; Basabe, 2018; Basabe \& Germani, 2014). As I had often labeled my practice critical but had always felt uncertain about that criticality, I realized that that uncertainty could only be dispelled by the proper reflection that would be guided by the research question: To what extent was I being critical?

\section{Literature Review}

My autoethnographic narrative was framed by three interpretative contexts from which the data collected were read and analyzed: (a) agency in practice theory, (b) teacher education, personhood, and the public interest, and (c) criticality in ELT. 
Agency in practice theory. Holland, Lachicotte, Skinner, and Cain (1998) provided an innovative answer to the issue of how human beings deliberately relate their personal concerns to the social circumstances that surround them. Agency in practice comes through "the space of authoring, the conflictual and continuing dialogic of an inner speech where active identities are ever forming" (Holland et al., 1998, p. 169). The event of authoring oneself constitutes the internal site of subjectivity. Imaginatively, human beings constantly create figured worlds, or "socially and culturally constructed realms of interpretation in which particular characters and actions are recognized, significance is assigned to certain acts, and particular outcomes are valued over others" (Holland et al., 1998, p. 52). Thus, agents create and continuously recreate their worlds in pursuit of the goals that they value, but those goals are constantly contoured by the figured worlds they are always in the process of generating. In this current research, agency in practice theory would explain my decision-making processes of the teacher educator under analysis, as well as my action and my agency, or my "ability to pursue the goals that one values" (Archer, 2000, p. 258).

Teacher education, personhood, and the public interest. In the ensuing autoethnography, I authored my action in the figured world of teacher education. The underlying values of that realm could be explained by recurrence to the conceptual diptych public interest/cultivating personhood suggested by Hansen (2008). The public interest can be understood as a social process "that both emerges from and is enacted by human beings seeking to bring activity to meaningful completion" (Hansen, 2008, p. 18). Teacher education is a practice that occurs in view of the public interest and, as such, it should go further than any particular concern or theoretical position.

However, the public interest is necessarily informed by individual personhood. There is in all social endeavors a personal element based on the ability of human beings to choose and decide their agency. In that vein, Hansen (2008) stated that "teacher educators can only benefit from rendering visible their notions of personhood and how these jibe with their assumptions about education and society" (p. 22), or, in other words, making explicit their figured worlds. All teacher educators have a sense of purpose, a vision, and that is not merely drawing on the social but usually self-concerned and particularly personal. It is no wonder then that Hansen (2008) suggested for current times "reconstructing how teacher educators perceive their various interests and commitments" (p. 20), if we still believe in a democratic society.

Criticality in ELT. Criticality has taken two directions in ELT: critical thinking, which aims at developing students' skills in terms of logics and decision-making, and critical pedagogies, which attempt to relate the classroom to its wider social context and to put into practice a transformational pedagogy (Banegas \& Villacañas de Castro, 2016). The work presented in this article could be inscribed under the second label, critical pedagogies, since my praxis under consideration was mostly inspired by readings of Freire (2009), Freire and Faundez 
(2013), and specifically of Freire and Shor's (2014) account of the queries and qualms in the everyday experience of teachers' advancement of a critical agenda. It has been claimed, however, that relatively few scholars in ELT have called for any radical or revolutionary change in society, most possibly derived from the tendency to language objectification favored by the field (Chun \& Morgan, in press).

This current research study could also be said to respond to the demands of what Chun and Morgan (in press) labeled the "second wave" of critical research in that it addresses issues of a teacher educator's identity in connection with the critical. In his introductory work to Critical Applied Linguistics (CALx), Pennycook (2001) suggested at least three variations for the use of the term critical. First, critical may be seen "as always engaging with questions of power and inequality" (p. 4). Second, critical may also mean "taking social inequality and social transformation as central to one's work" (Pennycook, 2001, p. 6). Last, Pennycook (2001) proposed that critical means crucial in the sense that, through critical praxes, Applied Linguistics was on the verge of moving into a new state of being: CALx. These three directions implicit in the term critical will be traced in the vision and action of the teacher educator examined in this paper, as well as in the succinct but complex definitions offered in this section that will positively inform this autoethnography.

As already suggested above, I had often labeled my practice critical. However, I had no clear grounds for the use of that label. Therefore, I devised an exploratory research question: To what extent was I being critical? As the data analysis proceeded, I realized the presence of elements in my criticality that I would categorize as mostly discursive, generally belonging in the realm of vision, and, as a result, I framed a second research question: How was my criticality voiced - as a vision or turned into action? Through this research paper, I seek to describe my vision, what I believed in, and my action, what I actually did, in order to consider as a final point how these could be read as critical in view of the interpretive frameworks briefly summarized in this section.

\section{Method}

Setting. This work was based on my experience while teaching the course on contemporary English literature at UNLPam. English Literature II was a subject taught during the second term of the fourth year of the ELTE program; its corpus primarily comprises the literature of the UK and the USA in the 20th century. About 15 students take the course every year, and it is taught along 17 weeks in the spring term (August to November) in weekly periods of 2 hours. Most students are female, and they are usually 22-25 years old when they take the course. The contents of English Literature II officially comprise the three key styles of culture in the $20^{\text {th }}$ century, modernism, post-modernism, and post-colonialism (UNLPam, 2013). However, though these contents are still covered, the course has been 
methodologically transformed into a reading seminar. In every lesson, the students explore in small groups, arranged as open spaces of debate and inquiry, themes selected from an initial list assembled as a class. At the moment this research was carried out, there were 10 students taking the course. Eight of the students were female and two were male, nine of them were ages 22-23 and one was 27, and all of them had completed the third year in the program. ELT is one of the four-year programs that can be studied at the School of Human Sciences at the above-mentioned university in which about 150 students are enrolled. UNLPam is a small institution and the only state university in the province of La Pampa, in central Argentina.

Participant. The research study was focused on me, the author of this paper. I graduated as a teacher of English from UNLPam in 1995, and started working there as an Assistant Teacher for English Grammar III in 1996. Three years later, I applied for a vacant position in English Literature II and started teaching literature in 1999. I became tenured in 2003, when I had already begun studies in pursuit of a master's degree in English Literature at the National University of Rio Cuarto in 2007. I was sponsored by the British Council to pursue studies to obtain a master's degree in Cultural Studies and ELT in the UK in 2003-2004 and by the Fulbright Commission to obtain a doctorate in Education in the United States from 2008 to 2011. It was in the latter case in which I became acquainted with critical pedagogies, as the education programs offered at Southern Illinois University, where I studied, was mainly based on the tenets of that position. As a result, on my return to UNLPam, I decided to use critical literacy in the literature course I taught and to conduct a small-scale research project on its practice.

Procedure. At the point in my career when I was writing this autoethnography, I felt that I could not separate myself from the critical perspectives that had structured my underlying epistemologies. I had done Critical Discourse Analysis (CDA), belonged to a Critical Literacy Special Interest Group (SIG), studied literature from mostly feminist and post-colonial perspectives, and most readings I was doing at the time were in the area of critical pedagogies. Critical, then, in the sense used by Lancy (1993), was the paradigm that best represented the way I approached this research. I had been already acquainted with autoethnography, but, until that moment, I had not dared to put the methodology into practice. Even though the research became thoroughly autoethnographic in nature, the intention was that it did not become purely narrative. Following Muncey (2010), then, it was planned as an analytical autoethnography. In it, as a researcher and not as a mere narrator/ informant, I became the visible member "committed to an analytic [emphasis added] research agenda focused on improving theoretical understandings of broader social phenomena" ( $p$. 375). Those broader social phenomena encompassed in this case teaching literature critically in the ELTE program. Following Chang (2007), the autoethnography also constituted an interactive introspection, in which both the research assistant and I would interview each other 
in order to relive the experiences under analysis and examine them critically. The research followed the processes of data collection and data analysis described below.

Data collection. At first, the source of data comprised ten observations (Obs.) that a research assistant would make from August to October 2016, but once it was decided that the research would be specifically focused on the practice of the teacher educator, other sources were added for the sake of triangulation and for further trustworthiness. From then onwards, it was assumed that an instance of systematic self-observation was to be produced. Thus, two key documents were included, which result highly informative in the interpretative stage of the data analysis. Those were: (a) a subjectivities statement (SS) that I had composed in May 2015 as part of another study (Basabe, 2016), and (b) my teaching diary (TD), which consisted of 12 entries (E) written during the same period about the research assistant's observations. Moreover, the research assistant also designed and conducted two semistructured interviews, which took place in October 2016, immediately after the research question was established and when all previous data were already coded. Finally, minor sources of data, including documents, such as the syllabus, lesson plans, and class handouts, were also collected and scrutinized.

Data analysis. The descriptive stage of the study was mainly informed by the notion of analytical autoethnography. The data sources were coded in a data-driven mode (Gibbs, 2007). The categories for content analysis were highlighted in the sources of data under consideration. Comments were also made about any particular element that was deemed worth either explaining or expanding upon. An initial broad classification of codes was suggested as both researchers proceeded through the analysis: what I believed in, my vision, was not necessarily informing what I was actually doing, my action. Therefore, both vision and action were kept separately and coded accordingly, and once the data coded under one label reached its saturation point, we would try to summarize it under a general narrative statement.

The concept of interactive introspection informed the explanatory level of analysis. That involved the research assistant's peer checking of the coded data and a series of meetings for discussion, the last one resulting in an interview on the basis of the written autoethnography, which provided not only the outsider perspective but also external data to confirm or dispute the internal data generated from my personal reflection. Data analyzed at the descriptive stage of the research inform mostly the results section of this paper; those interpretations emerging at the explanatory stage comprise the discussion section.

The interweaving of data collection, analysis, and interpretation ultimately led to the production of the autoethnography. That involved "moving back and forth between self and others, zooming in and out of the personal and social realm, and submerging in and emerging out of the data" (Chang, 2008 p. 5). Some limitations must be pointed out, though. 
On the one hand, this autoethnography may be excessively focused on me in at the expense of others. On the other hand, the research assistant's stance towards my interpretations was often positive, which is understandable in view of her critical engagement with the proposal and the fact that she had been my student at university. Last, issues such as class or genre, among others, were not explicitly examined, which could have caused the emergence of other relevant insights from the analysis. Nevertheless, they are indirectly revealed throughout the results.

\section{Results}

Here, brief narrative accounts of the data-driven coding will be offered, preceded by a statement summarizing the code as heading. Interspersed with the results are explanatory comments intended to provide the text with the analytical quality of an autoethnography.

\section{Vision: What I believed in}

Literature as part of life. That was a recurrent idea in my narrative. It explains the personal-growth approach to teaching literature that I had tried to put into practice since the early 2000s. The notion appears in my subjectivity statement, where I quoted Woolf's (2000/1925) dictum that "life had its way of adding day to day" (p. 47) as a motto that helped me overcome challenging situations in life. Therein, it is also mentioned that a student once told me that he expected literature to teach him "something that is valuable for life" (SS). Moreover, in one of my diary entries, I recorded having met a group of students in the corridors of the university and having generated in them an unexpected interest in the lives of Virginia Woolf and W. B. Yeats. After that conversation, I concluded that "there are all these intertextual relationships and these relationships with real life and all of these flood (sic) our relationship with literature" (TD. E. 6). Lately, I found a relatively more theoretical statement about the issue, and I used it to start the course on English literature in 2016: "This is literature as a fact of life -there is nothing to be afraid of in looking closely at the facts of life” (McRae, 1991, p. 59) (Obs. 10.08.16).

Literacy as a basis for language teaching. This belief had its grounds in my own education. In my statement of subjectivities, I stated, "I have always used literature and literacy as strategies" (SS). At primary (elementary) school, I thought, "there was something that 'disclosed' who I was, and that was my social class" (SS). I felt that, due to my workingclass origins, I did not belong on the team of "good students" and that I needed to find "an ability that would make of me a good student" (SS). It was thus that I turned to reading and writing extensively. As an adolescent, I turned into an introvert and became rather lonely. Literature then became an "escape" from living in a small village, and when I had to leave it and go to university, I would have chosen Spanish but I chose English because I thought 
I had to study something more profitable. Once I graduated, literature was, together with textual grammar, the two areas in which I began working, and I gradually found that the connection between both was stronger than what I had supposed at the very beginning.

Throughout this narrative, literacy points at a competence broader than reading, understood in the traditional sense in use in ELT settings, and encompassing all forms available within the teaching and learning enterprise to interpret and make sense of the world around us. Literature initially embodied for me a way of gaining access to the cultural aspects of English as a foreign language but then turned into motivation for personal growth. I replicated this personal process undergone in my relationship with literature when I progressively turned the literature course I taught into a literacy class in which I modeled different approaches to text and different ways of teaching. In that way, I attempted, first, to inscribe my practice in the craft tradition. For Coldron and Smith (1999), teachers usually inscribe their practices within a series of traditions: the craft, the moral, the artistic, and the scientific. In a paper that I wrote for my PhD studies (Basabe, 2010), I positioned myself in the craft tradition. Teaching in that tradition involves following a patterned plan in order to achieve a pre-determined end but also responding spontaneously to the unforeseen scenarios that constantly emerge in the context of the classroom. Second, even though I considered that teaching literacy was necessary, I tried to bridge that personal goal with what was institutionally required from me, i. e., that I teach literature. Last, I made those contradictory decisions about the course explicit to my students, and they responded accordingly (Obs. 10.08.16).

Criticality in education and society. This I also saw as stemming "from my own awareness of class consciousness and of having used literacy and literature as a tool to overcome my initial social constraints in educational institutions" (SS). More often than not, I openly claimed that I disregard class stratification as an issue to be discussed as part of the literature class, but covertly, I tried to use social class as a valid category of analysis and to generate a certain degree of class-consciousness. I seldom expressed those views publicly, even though, as attested by the research assistant, I repeatedly contemplated those issues in my teaching diary. Perhaps, I just concealed them from my students in an attempt to have them "walk the critical walk" (TD. E. 3). I considered that issues concerning or experienced by the working class were usually left aside from either the literature curriculum or the entire ELTE program at the university where I worked. Therefore, once I could openly start acknowledging my working-class origins, sparking discussions about class in the literature classroom made me feel that I was making an apt and necessary contribution to a critical debate about society and education in the context of ELT.

Critical pedagogies in action. This was a very strong wish of mine, and the reason why, when I was given a full-time tenured position and the first chance to conduct a research project, I chose to design and carry out a study devoted to critical literacy in the literature 
classroom in ELTE (Basabe \& Germani, 2014). However, I still felt there were "issues I wanted to talk about and I could not," to which I added that "I can't or I don't know how to get disengaged from the logics of modernism, postmodernism, and postcolonialism" around which I had used to organize the syllabus until 2009 (TD. E. 12).

However, I had established for myself some basic principles about the shared construction of knowledge, and I tried to tackle key social issues such as identity, gender, and class in my literature classes. Moreover, I felt "happy" when I recognized hints of critical responses from my students (TD. E. 12). Examples of this were: the time "when students 'reacted' to Steinbeck's (Steinbeck, 1965/1937) Of mice and men and to the tasks I proposed to them" (TD. E. 2), or "when they got to the core of a poem "Hunger"” (TD. E. 3), in which cases my views coincided with the ones registered by the research assistant: "Even though the topic is not pleasurable, they are enjoying it!" (Obs. 20.08.16). Despite the positive attitude of my students, at some point during the term, I concluded that "I am tired of teaching. Of teaching and nobody caring. Of teaching and suffering the effects of what is not achieved... Of teaching and seeing the world not changing in the direction I want it to change" (TD. E. 8). Then, I guessed that that was the perpetual dilemma of those in the process of becoming critical educators: our vision of education will hardly become true during our lifetimes, and therefore, we feel the strain.

\section{Action: What I did}

Teacher-centered practices. Though not always lectures, the classes I taught were, according to the observations, "excessively guided" (Obs. 10.08.16, 20.08.16, 2, 14.09.16) and "very teacher-centered" (Obs. 13.10.16). Sometimes, I even took control of the interpretation of literary texts, and, as a result, the students became reluctant to speak (Obs. 14.09.16). I felt, however, that "there are strong expectations that I explain because I am (apparently) the one who knows; that makes me sometimes unable to manage my suggestions that they become responsible of their own readings" (TD. E. 3). On another occasion, I was perceived as "theorizing too much, which limited the students' interpretation from the very beginning" (Obs. 14.09.16). That made me feel the tug of ambivalence, and in a diary entry I recorded: "I have a contradictory feeling: I would also like to provide them with sociological readings of literature, but that would make little space for their own readings" (TD. E. 3). Yet, one element that stood out in my teacher-centered practice was the use I made of the blackboard, which, somehow hyperbolically, was described by the research assistant as "breaking with traditional ways" (Obs. 19.10.16). I had never reflected on that, but what I acknowledged I had always tried to do is, in accordance with the research assistant's observations, to "guide students' interpretation" (Obs. 22.08.16) and "just contribute to organize ideas" (Obs. 14.09.16) through the creation of a shared interpretation of the literary text. This was done by carefully triggering concepts from the students, extending from their own readings of the 
literary texts and limiting my intervention to the creation of shared web-diagrams on the blackboard. There, I only suggested different relationships among the notions they offered, and I discarded suggesting myself any of those that would force them to understand the texts the way I had previously interpreted them.

Deconstruction of teaching practices. Together with the assessment criteria for the course (Obs. 10.08.16), there was always a clear disclosure not only of the course organization but also of the teaching strategies in use. In one of the first lessons in 2016, for example, I claimed, "the course follows a traditional teacher-centered logic at the beginning and gradually moves towards a student-centered perspective at the end" (Obs. 20.08.16). That comment coincided with the sense of "disorganization," reported by some of the students in their answers to my survey (TD. E. 12). However, it was through my diary that I once realized how I deconstructed my teaching practice or, in other words, how I disclosed to them all of what usually stays "behind the scenes" (TD. E. 5) of classroom discourse. That day, a student felt free to comment, "Oh God! So much fuss because we haven't read!" (TD. E. 5), and as in fact most had not read the end of the play they were analyzing, I asked those who had to make utmost efforts not to disclose the end. That way, I made evident, perhaps inadvertently, the constructed quality of the literary text. In other cases, I made remarks about the students' endeavors, such as some well-crafted pieces of creative writing or the ironic "we are in kindergarten" when they did not want to work (Obs. 19.10.16). That was sometimes criticized because of the straightforwardness of the act, as recorded in some of the students' surveys, but also oftentimes, when remarks were tactfully delivered, regarded as a token for "taking into account different learning styles" (Obs. 10.08.16).

Personal involvement in the teaching-learning process. Even though the students were apparently motivated when they started the course (Obs. 10.08.16), "the first feelings I had were anguish, instability, frustration... Uncertainty!” (TD. E. 1). That demonstrates my sense of permanent worry, and my deeply held notion that every single move I made was an enterprise of almost titanic dimensions. That was, above all, the way I lived teaching, and although the feeling might read quite disheartening, it turns into an empowering circumstance, as I gradually allowed my students 'views enter the teaching process and tried to involve those students at the personal level, too. I valued one student's insistent connections of many texts that they were reading with the film Fifty Shades of Grey (Brody \& Taylor-Wood, 2015) (TD. E. 1 and 6), for instance, and I provided detailed explanations to students that particularly tended to disagree with the shared interpretations of the class (Obs. 20.08.16). However, when I noticed "more and more resistance to my readings," I realized that "I feel good about this, but then I could do very little about it" (TD. E. 4, Obs. 20.08.16 and 19.10.16). One student, though, once voiced her view that "this is not time we wasted" (TD. E. 8), which I interpreted as an acknowledgement of the usefulness of class discussions in which she was expected to get involved at the personal level. 
Now, as for the actions that I consciously carried out to involve my students with their learning at the personal level, two can be particularly highlighted: the selection of literary texts and my intention to foster student-generated discussions in the literature classroom. The former had become the highlight of the course in the students' surveys in the last three years, and I also felt pleased with the literary works from which I chose to develop materials: Joyce's (1996) "Eveline," a story about a girl having to make a crucial decision in life; Tóibín's (2010) "The Street," the story of a gay relationship between Arab migrants in Barcelona; or Berryman's (1989) "The Ball Poem," a poem about the epistemology of loss. These somehow display my critical position towards society and education mentioned above.

I tried to continually foster student-generated discussions in my literature classes, as in the case when I apparently adopted "inconclusive, erratic perspectives so that the students discuss and defend their own perspectives" (Obs. 19.10.16), or when, in an attempt to persuade them, I affirmed, "We need to discuss. That's the mood of this course. Otherwise, you think I am always right and that's not true" (Obs. 14.09.16). Their interventions were not actually as many as I had wanted them to be, yet, one of them concluded that eventually "every one of those who take the course gave every reading or interpretation his or her personal 'touch"' (student's survey as registered in TD. E. 12). At some point, I concluded that "I feel something like (sic) each one of them [the students in the group] must have seen something which in a way has helped them think there is the chance of becoming critical... Some attitude, some text, some activity" (TD. E. 12).

Critical tasks in literature. In that vein, I gradually changed the approach to teaching literature from a cultural model towards a personal-growth model, and I consequently reorganized the contents of the course into the conflicts that are usually present in a literary work: man versus nature, man versus man, man versus society, or man versus himself. In that way, I provided my students with a framework for reading and interpretation expecting personal responses from them but that does not leave analysis aside. Examples of that way of teaching included choosing one among a set of characters, and using the persona they selected, retelling their version of the story or class discussions in which groups were assigned to discuss the actions of one character but were later asked to change their perspective to that of another one (Obs. 19.10.16). At some point during the course, I wrote an assignment based on the students' particularly biased judgments of the events in a literary text:

Smith is a poor adolescent in a youth detention center in Essex in the 1950s. His father has recently died. Lennie is a migrant worker travelling with his friend in rural California in the 1930s. Smith has robbed a local shop; Lennie has killed a woman. Yet, you feel pity for the latter, not for the former. Give 3 (three) sound reasons for each case in which you explain why you judge them that way. 
Tasks like these helped students position themselves in the place of certain characters and see the world through their socio-cultural and ideological circumstances. That reality triggers from the students mostly personal and quite creative responses, together with the fact that the literary works selected for the course generally dealt with the lives of typically underrepresented subjects, e. g. Black women, Pakistani gay men, Southern laborers, and juvenile delinquents. This is evident in some of the observations (Obs. 09.11.16 and 11.11.16). One student reported, "before this literature (sic), I had only paid attention to the plot of the stories and to themes, without actually considering how they were constructed through the language" (student survey recorded in TD. E. 12). I felt, though, that having achieved that response did not necessarily mean I had taken them to the critical positions that I had tried to reach.

\section{Discussion}

In this section, I address the results presented above mainly from the perspective of Pennycook's (2001) three variations for the use of the term critical. At some points, I suggest a broader scope, and I discuss my vision and action in the terms specified by Hansen's (2008) notion of personhood or in view of Holland et al.'s (1998) agency in practice theory.

In Miedo y Osadia, Freire and Shor (2014) recommended at least three steps to be followed in the critical direction: (a) to overcome the fears of both teachers and students by gradually sharing a common critical language, (b) to keep structure and rigor around critical work, and (c) to apply a dialogical methodology and a situated pedagogy. In view of the results, it could be stated that there were partial accomplishments in my action, as reported by myself, especially in terms of me having tried to follow tenets (b) and (c). I attempted to put into practice a form of critical pedagogy based on my own personal and teaching experience. I had realized that literacy had become a major issue for my students, and I had therefore decided to change the literature course I was assigned to teach into one highlighting critical literacy and a personal-growth model in its approach to literature. I also made utmost efforts to provide that change with a relative degree of structure and rigor through my personal involvement with and my continuous deconstruction of the teaching process. In brief, I achieved, through my action, moving in the direction of providing the critical with that sense of cruciality hailed by Pennycook (2001).

However, I felt I could not set a clear critical agenda either at the personal or the institutional level. Still following Pennycook's (2001) variations for the term critical, it can be stated that, even though acknowledging my concern about class stratification, for example, I had seldom taken social inequality or social transformation as central to my work. Moreover, 
I reported to have hardly gotten engaged with questions of power and inequality, except sporadically in the restricted context of teacher-student interactions within the classroom. In that, I might have been unable, as suggested by Freire and Shor (2014), to overcome the fears of becoming critical by gradually sharing a common critical language with colleagues and students, a vision that I could have turned into action through exercising my own agency in the context of ELTE.

There also seems to be, in my persistent questioning attitude, an inability to actually measure my capacity to reach a transformational practice. Through my teaching and research, I was able to make my personal commitment with a critical pedagogy explicit in my working context, and I represented that as bridging my personal inclinations with the public demands of the purpose or teacher education, in the sense described by Hansen (2008). I was restricted, though, in my vision due to a persistent wariness of the appropriateness of keeping a critical position in my teaching in view of the course and the population I was working with and of my perceptions of the institutional demands of my context, which I perceived as imposing on me a merely linguistic approach to teaching. These constraints, moreover, are very much in accordance with the determined tendency in ELT to treat language as a set of neutral, decontextualized forms and structures (Chun \& Morgan, in press). As a result, I could not configure a truly enabling figured world from which to pursue the goals that I valued, and I only authored minor actions in that direction. There was in me, consequently, still much to be carried out in terms of what Holland et al. (1998) called improvising artfully in figured worlds.

\section{Conclusion}

In response to my initial research question, I must conclude that I was being critical only to the extent to which I felt I was allowed by my figured world a context in which I tended to represent both the population I was teaching and the institutional demands as restricting my agency. Even though the notions of the critical informing my practice were certainly drawing on wider disciplinary understandings of education and society than those of ELT, my vision and action were firmly grounded in the settings and practices proper to the field. As such, it should be concurred with Chun and Morgan (in press) that they were not ready to set any radical or revolutionary agenda in ELTE.

In response to my second research question, it should be stated that the event of writing my analytical autoethnography itself became for me a turning point between how my criticality was voiced as vision and how it was turned into action. As reported in the section on results, before this step was made, I had only made minor attempts at adopting a critical stance or assuming a working-class position only within the classroom. Together with an article in which I demonstrate my ways of teaching (Basabe, 2018), this text may help bridge 
the gap between my vision and my action since I am assuming now a public position in the critical direction. I tended to grow critically, however, only to the extent that the figured worlds I framed for myself had let me do so.

Further studies are needed that inform how teachers exercise their agency and their capacity to become critical, and many more should probably be written in an attempt to show how those abilities are constrained by the geopolitics of knowledge and the coloniality of power. Analyzing these constraints, however, would go beyond the aims of this research: to describe my vision and my action and to consider to what extent they were critical.

Overall, criticality cannot be measured in absolute terms, either in vision or in action. Teachers, as well as teacher educators, can only grow critically, and they should be considered critical as long as they continue growing in the critical direction. It is hoped then that this work will provide new insights about the issues of agency and personhood of a teacher educator so that it inspires other teachers who aspire to transform their practices in order to turn them into critical praxes.

\section{References}

Archer, M. S. (2000). Being buman: The problem of agency. Cambridge: Cambridge University Press.

Arriaga, M. I., \& Germani, M. P. (2018). Towards a pedagogy of possibilities: Critical literacy through literature in ELTEd. ReLingüistica Aplicada, 22. Retrieved from http://relinguistica. azc.uam.mx/no022/art01(Germani\&Arriaga).htm

Banegas, D. L., \& Villacañas de Castro, L. S. (2016). Criticality. ELT Journal, 70(4), 555-457. http:/ / doi.org/10.1093/elt/ccw048

Basabe, E. A. (2010). Teaching as craft. Unpublished manuscript. Southern Illinois University. Carbondale, USA.

Basabe, E. A. (2016). La literatura en el profesorado en inglés: Formadores docentes y modelos curriculares. In M. V. Gastaldi, \& E. I. Grimaldi (Eds.), Politicas lingüisticas y lenguas extranjeras en el nivel superior (pp. 99-109). Santa Fe: Universidad Nacional del Litoral.

Basabe, E. A. (2018). ¿Puede la literatura promover el pensamiento crítico en el Profesorado en Inglés? MEXTESOL Journal, 42(3), 1-16.

Basabe, E. A., \& Germani, M. P. (2013). Literacidad crítica y literatura en la formación docente del profesor de inglés. Research project approved by the Directive Council, School of Human Sciences, National University of La Pampa, (Res. No 408-13). Santa Rosa, Argentina.

Basabe, E. A., \& Germani, M. P. (2014). Reading for life: The Critical literacy and literature project at UNLPam (2013-2016). Argentinian Journal of Applied Linguistics, 2(1), 32-41. 
Canagarajah, S. (2012). Teacher development in a global profession: An autoethnography. TESOL Quarterly, 46(2), 258-279. http://doi.org/10.1002/tesq.18

Chang, H. (2008). Autoethnography as method. Walnut Creek, CA: Left Coast Press.

Chun, C. W., \& Morgan, B. (in press). Critical research in English language teaching (to appear in the Springer Second Handbook of English language teaching).

Coldron, J., \& Smith, R. (1999). Active location in teachers' construction of their professional identities. Journal of Curriculum Studies, 31(6), 711- 726.

Farrell, T. S. C. (2011). Exploring the professional role identities of experienced ESL teachers through reflective practice. System, 39(1), 54-62. http://doi.org/10.1016/j.system.2011.01.012

Farrell, T. S. C. (2012). Surviving the transition shock in the first year of teaching through reflective practice. System, 61, 12-19. http://doi.org/10.1016/j.system.2016.07.005

Freire, P. (2009). Pedagogía del oprimido (3rd ed.). Buenos Aires: Siglo XXI. (Original work published 1970).

Freire, P., \& Faundez, A. (2013) Por una pedagogía de la pregunta: Crítica a una educación basada en respuestas a preguntas inexistentes. Buenos Aires: Siglo XXI. (Original work published 1985).

Freire, P., \& Shor, I. (2014). Miedo y osadía: La cotidianidad del docente que se arriesga a practicar una pedagogía transformadora. Buenos Aires: Siglo XXI. (Original work published 1987).

Gibbs, G. (2007). Analyzing qualitative data. Thousand Oaks, CA: Sage.

Hansen, D. T. (2008). Values and purpose in teacher education. In M. Cochran-Smith, S. FeimanNemser, D. J. McIntyre, \& K. Demers (eds.), Handbook of research in teacher education: Enduring questions in changing contexts ( ${ }^{\text {rd }} \mathrm{Ed}$.) (pp. 10-26). New York: Routledge.

Holland, D., Lachicotte, Jr., W., Skinner, D., \& Cain, C. (1998). Identity and agency in cultural worlds. Cambridge, MA, \& London: Harvard University Press.

Lancy, D. (1993). Qualitative research in education: An introduction to the major traditions. New York \& London: Longman.

McRae, J. (1991). Literature with a small "l". London/Basingstoke, RU: Macmillan.

Muncey, T. (2010). Creating autoethnographies. Los Angeles: Sage.

Pennycook, A. (2001). Critical Applied Linguistics: A critical introduction. Mahwah, NJ, \& London: Lawrence Earlbaum.

Richards, J. C., \& Lockhart, C. (1996). Reflective teaching in second language classrooms. Cambridge: Cambridge University Press.

Tsui, A. B. M., (2007). Complexities of identity formation: A narrative inquiry of an EFL teacher. TESOL Quarterly, 41(4), 657-680. http://doi.org/10.1002/j.1545-7249.2007. tb00098.x

UNLPam. (2013). Plan de estudios del profesorado en inglés. Santa Rosa, Argentina. Retrieved from http://www.humanas.unlpam.edu.ar/fchst/Institucional/SecAcademica/Planes/resolucion_2013_026_prof_ingles.pdf 


\section{Films and Literary texts}

Berryman, J. (1989). The ball poem. Collected Poems, 1937-1971. New York: Farrar, Straus, \& Giroux. (Original work published 1937).

Brody, J. (Producer), \& Taylor-Wood, S. (Director). (2015). Fifty shades of Grey [Motion picture]. USA: Focus Features.

Joyce, J. (1996). Dubliners. Harmondsworth, Middlessex, England: Penguin. (Original work published 1914-1915)

Steinbeck, J. (1965). Of mice and men. Harmondsworth, Middlessex, England: Penguin (Original work published 1937).

Tóibín, C. (2010). The empty family. New York: Scribner.

Woolf, V. (2000). Mrs. Dalloway. Harmondsworth, Middlessex, England: Penguin (Original work published 1925). 